\title{
Canadian contributions to pulmonary anatomy and pathology
}

\author{
James C Hogg OC MD PhD FRSC
}

$\mathrm{T}_{\mathrm{p}}^{\mathrm{h}}$ he contributions of Canadians to pulmonary anatomy and pathology have been recognized internationally for almost a century, and the published abstracts of the 2007 meetings of the American Thoracic Society indicate that Canada has a bright future in this field. The introduction of computed tomography (CT) has had the greatest impact on the practice of chest medicine within living memory, because it allows the gross anatomy of the lung to be visualized noninvasively. The more recent introduction of micro-CT has also provided an opportunity to investigate samples of the lung at the microscopic level without destroying the tissue. Micro-CT has made it possible to apply the newer techniques of laser capture microdissection and real-time polymerase chain reaction to specific lung structures selected by CT and micro-CT, and to ask questions that could not even have been imagined a few short years ago. The introduction of magnetic resonance imaging of hyperpolarized gases has also made it possible to measure diffusion distances within the gas phase of the lung to obtain new and perhaps more accurate information about the size of normal gas-exchanging units during life, as well as the extent of their destruction in disease. These powerful tools are beginning to provide insight into the molecular events that underlie the basic processes of inflammation, tissue repair and tumour biology, which may provide solutions to the most troublesome problems related to pulmonary medicine.

Although many Canadians have and are currently contributing to the flow of this new knowledge, the present review focuses on contributions made by three eminent researchers, all of whom who have been dead for at least 10 years. These three researchers established a tradition of excellence in the field of pulmonary anatomy and pathology in Canada that has provided a solid foundation for future achievements.

\section{CHARLES CLIFFORD MACKLIN}

Charles Clifford Macklin was born in Toronto, Ontario, in 1883 and died in London, Ontario, in 1959. He was the eldest of seven children and took an entry level job in the medical department of the Canada Assurance Company, where his talent was recognized by a physician who encouraged him to go to medical school. Macklin took this advice seriously, hired a tutor and studied evenings while continuing his day job at the Assurance Company, and he was accepted into medical school at the University of Toronto, Ontario, in 1908 (1). He won the James Richardson Fellowship in Anatomy in 1912, which allowed him to take time off from medical studies and try basic research. He received the MB degree in 1914, an MD in 1916 and a $\mathrm{PhD}$ in anatomy in 1924, all from the University of
Toronto. Macklin was appointed as an assistant in anatomy at Johns Hopkins Medical School, Baltimore, Marlyand, after receiving his MB degree in 1914, and moved back and forth between Toronto and Hopkins while he continued to pursue his MD and PhD degrees. He was working as an associate professor at Hopkins when he responded to a call to return to Canada and become the Professor of Anatomy at the University of Western Ontario, London, Ontario, in 1921. He remained at Western until he retired from academic life in 1953, and because the rules of the day prevented retired faculty from using University facilities, he continued to work at home "trying to do a little microscopy with some slides and an old microscope". Many of his publications have become classics in the field of functional lung anatomy and pathology, including some completed after retirement. One hopes that that particular "old microscope" that he used in retirement is displayed in a suitable glass case somewhere to illustrate what great work can be done with an instrument that would be considered primitive by today's standards $(1,2)$.

My first realization that Canada had produced a scientist of this stature came at a Respiration Group dinner held during the annual meeting of the American Physiological Society in 1976, where a group of distinguished American scientists presented an appreciation of his work. Certainly, I can think of no greater measure of the impact of anyone's work than to have acknowledged leaders in different aspects of the subject recount the remarkable insights that a person, whom none of them had ever met, had contributed nearly 20 years after his death. I regret I did not attend this particular dinner, but the published summary of their 'appreciation of Macklin's work' was a major source for this section of the review (1).

Dr John Clements, of surfactant fame, spoke about Macklin's insight into the function of the surface lining of the lung. He pointed out that when most morphologists were arguing about whether the alveoli were covered by an epithelium, Macklin was interested in an extravagantly thin, aqueous film that covered the epithelium (3). He also recognized that the granular pneumocytes or epicytes, now termed 'type 2' cells, were secretory in nature and contributed to this surface film (4). By 1954, he had published his landmark article, "The pulmonary alveolar mucoid film and the pneumonocytes" (5), which provided clear insight into what this fluid layer must look like. Measurements of the size of the pulmonary alveoli that he had made with Stanley Hartroft during World War II (6) made him realize that the surface tension of this lining layer must be low, because a high surface tension would cause the alveoli to collapse due to their small radii of curvature.

Pathology and Laboratory Medicine, University of British Columbia, Vancouver, British Columbia

Correspondence: Dr James C Hogg, Emeritus Professor of Pathology and Laboratory Medicine, University of British Columbia, Vancouver,

British Columbia. Telephone 604-682-2344 ext 62949, fax 604-806-8351, e-mail jhogg@mrl.ubc.ca 
Although he did not specifically state that the granular pneumocytes secrete surfactant, he recognized that what he called myelogens (and what are now called phospholipids) were present in the alveolar lining layer and also connected to the osmiophilic lamellar bodies of the granular pneumocytes. This was a remarkable insight that remained underappreciated until the surface of the lung was rediscovered by physiologists and anatomists equipped with much better tools than those available to Macklin.

Dr Sol Permutt spoke of Macklin's seminal contributions to our understanding of the pulmonary circulation from his studies of the effect of lung inflation on the pulmonary vasculature. The consensus in his time was that the pulmonary vessels got smaller with positive pressure inflation because the alveolar pressure rose above vascular pressure and compressed the blood vessels. He was unhappy with this explanation because of experiments in which he filled the arteries and veins with latex and found that inflation of the lungs caused the latex to flow from the reservoir into the vasculature, whereas deflation caused the latex to flow out of the vessels back into the reservoir. When he did the same experiment with the vessels filled with blood or saline, he got exactly the opposite results. Latex is used to make casts of the large vessels because its surface tension is too high to get into the smaller ones and Macklin reasoned that there must be one set of vessels in the lung (now called the extra-alveolar vessels) that expand when the lung is inflated and a second set (now called the alveolar vessels) that is compressed. He also suggested that the filling of the extra-alveolar vessels during inspiration and emptying during expiration allowed the lung to act as an accessory pump in the circulation (7).

Macklin became interested in alveolar injury caused by overinflation of the lung when he observed that wedging a catheter in a small bronchus and locally overinflating the lung produced mediastinal emphysema (1). Anyone who has ever inflated an excised mammalian lung with either fluid or air notices that it begins to leak out of the lung at the hilum at higher levels of inflation, which is one reason why the maintenance of lung volume during fixation requires a constant head of pressure. Careful inspection shows that the fluid or air leaks from around the vessels rather than from the vessels themselves. Macklin reasoned that this occurred because the alveoli attached to the connective tissue forming the bronchovascular sheath break into it, allowing air to flow along the space within the sheath that surrounds the vessels and airways to the hilum (1).

Drs Norman Staub and Donald Proctor spoke on Macklin's contributions to the clearance of dust particles deposited on the alveolar surface from the lung. Macklin identified four ways in which this material was cleared: the transport of particles on the surface of the alveolar lining fluid toward the central airways, the ingestion of the particles by macrophages, clearance of both macrophages and free particles up the mucociliary escalator to the glottis and passage, and clearance of the free particles into the lymphatic system. In a brief but insightful publication (8) on the role of the 'dust cells' in the clearance of particles from the lung, he noted that dust cells (now called macrophages) were cleared out of the lung via the airways after they entered the airspaces; he found no evidence whatsoever that these 'dust cells' ever re-enter the tissue from the airspaces. He concluded that free dust particles that had either evaded the macrophages or were released from them entered the lymphatic vessels $(9,10)$. He also made important observations on the intrapulmonary lymphoid tissue, noting that the lung is equipped with "thousands of micro organs", whic he called "minute tonsils", interposed between air and lymph tissue (10). He referred to these tiny lymphoid organs as sumps and showed that they accumulated dust. His reference to them as minute tonsils was prophetic, in that we now appreciate that they are part of a mucosal lymphoid system, and that they can develop the germinal centres that are required to mount the humoral and cellular components of the adaptive immune response. The surfaces of these mucosal lymphatic collections are covered with epithelium, and differ from regional lymph nodes in that they have no afferent lymphatics and no surrounding capsule. The tonsils and adenoids in the lymphatic ring of Waldeyer provide classic examples of mucosal lymphoid collections, but they also exist in the Peyer's patches of the small intestine and in the appendix. Recent reports indicate that this is a common occurrence in the late stages of chronic obstructive pulmonary disease, after the lower respiratory tract becomes chronically colonized and infected. Macklin's identification of these structures was ahead of its time and represents an area in which new research is still shedding light on important mechanisms of lung disease.

One of Macklin's last papers (11) concerning the pathogenesis of lung carcinoma contains a much reproduced diagram that shows that he fully understood the distribution of the surface area in the lung. While the surface area is relatively small in the trachea and central bronchi, it increases rapidly in the bronchioles and becomes roughly the size of a tennis court in the alveolar surface. He postulated that the clearance of surface fluid from the alveoli to the glottis represents a rapidly narrowing raft that carries macrophages containing phagocytosed particles, as well as the free particles themselves. He postulated that the carcinogens deposited on the alveolar surface and cleared along this raft become concentrated as this fluid volume is reduced by reabsorption in the central airways to prevent the large volume of alveolar surface fluid from occluding the conducting airways. He postulated that this concentrated the carcinogens in the larger airways provides an explanation for location of tumours in these airways.

Surprisingly, his work does not seem to have been appreciated by the authors of the established textbooks on lung anatomy during his productive years. William Snow Miller made no reference to Macklin's work in the first edition of his book on the lung in 1937 and included only two references in the 1947 edition (1). However, von Hayek's book (12), published the year after his death, included many references to his work, and the frequent references to Macklin's now classic papers indicate that he laid the foundation for many of the improvements in our understanding of the functional anatomy of the lung that took place in the later half of the 20th century. Although neither a clinician nor a physiologist, his work provided key insights into the solution of some vexing physiological and clinical problems.

\section{DR WILLIAM MICHAEL 'WHITEY' THURLBECK}

Dr William Michael 'Whitey' Thurlbeck also enjoyed an international reputation as a teacher and investigator. Unlike Macklin, whom I never met, I knew Thurlbeck well, having been a postdoctoral student in his laboratory at McGill University, Montreal, Quebec, for three years, and his colleague and friend for more than 30 years. This long association gave me great respect for his scientific accomplishments, but I 
was perhaps too closely associated with him to be a fully objective judge of his work. Whitey was born in South Africa in 1928 and died in Vancouver, British Columbia in 1997. He spent his early life in Umtata in the Transkei, South Africa, where his parents were missionaries and received the bulk of his primary and all his secondary education at the Rondebosch Boys School in Cape Town. He studied medicine at the University of Cape Town, qualifying in 1953, and trained in anatomical pathology at the Massachusetts General Hospital in Boston, Massachusetts. He was a postdoctoral Fellow in Lynne Reid's laboratory at the Brompton Hospital in London, England, where he published work on the bronchial mucus glands $(13,14)$, and returned to Boston for further training before taking up his first faculty position as an assistant professor of pathology at McGill University in 1962. He remained at McGill until the early 1970s and, following a sabbatical year in Oxford in 1971 to 1972, he returned to McGill briefly before taking a position at the Midhurst Medical Research Institute outside of London, England. He returned to Canada as a professor and head of the Department of Pathology at the University of Manitoba, Winnipeg, Manitoba, in 1976, and moved to Vancouver, British Columbia, in the early 1980s, where he completed his career at the University of British Columbia.

Thurlbeck was an outstanding teacher at all levels. His undergraduate lectures were always extremely popular, and the course in lung pathology that he established and ran for the American College of Chest Physicians was one of the most popular postgraduate courses ever offered by the organization. He also edited a book on the pathology of the lung through two successful editions that included contributions from many of the faculty that he assembled for the American College of Chest Physicians course. The third edition was published eight years after his death, and was entitled Thurlbeck's Pathology of the Lung (15) to honor the lasting contributions he made to the subject. He also published over 250 papers in the peerreviewed literature, including a very important monograph on chronic obstructive lung disease (16). Although I have already confessed my possible bias, I think that his greatest contribution was his commitment to the quantitative study of lung anatomy and pathology, and the application of these data to improve understanding of lung function, lung growth and development, and finally, to the cellular and molecular events that occur in the lung.

Thurlbeck's commitment to quantification can be seen in his earliest work with Lynne Reid $(13,14)$, and was further developed in his collaborative work with Bates, Fraser and Macklem at McGill. Although centrilobular and panlobular emphysema were described by others before him, he made landmark contributions to the prevalence of emphysema in autopsy populations $(17,18)$ while providing new information about both the extent and severity of the different types of emphysema in human lungs (19). He also studied the pathology of chronic bronchitis (20), examined its relationship to emphysema (21) and showed that the ratio of bronchial gland to wall thickness - commonly called the 'Reid index' - was normally distributed in patients with this condition (22). His early collaboration with David Bates and Robert Fraser (23) led to a series of investigations in which measurements of lung surface area and the pathology of emphysema were correlated with measurements of lung function, chest $\mathrm{x}$-rays and clinical outcomes (23-25). His collaborations with Peter Macklem on the distribution of resistance in the lung, in which I participated as their postdoctoral fellow (26), showed that the small conducting airways are the major site of obstruction in chronic obstructive pulmonary disease. His work on the pathology of disease in the small airways $(27,28)$ continued after he reached the University of Manitoba, where he conducted an extensive series of studies on the physiological behaviour of excised human lungs with Norbert Berend, Jody Wright and others, which substantially increased our understanding of the relationship between the structure of these airways and their function (29-36).

Thurlbeck became interested in how the lung grew while at McGill, and he initiated new work in this area after he arrived in Manitoba. His studies on the growth of the human lung with Claire Langston and others $(37,38)$ confirmed previous reports showing that the total number of alveoli present in the human lung was complete early in life, and he extended them by showing that the addition of new alveoli was virtually complete by the age of two. He began examining the compensatory growth that occurs in one lung after the other is removed (39-41) and was encouraged by the fact that the lung that was left in place grew by producing new alveoli (42). He joined in the excitement over the report by Massaro and Massaro (43) showing that retinoic acid can heal the emphysematous lung destruction produced by elastase in rats. However, he also recognized that this repair may be unique to species like the rat, that continue to add alveoli to their lungs throughout their lifetime. He fully understood that this would be much more difficult to accomplish in human lungs, in which the process of adding new alveoli shuts down at the age of two years $(37,38)$. He fully realized the need for a complete understanding of the molecular control of alveolar addition in humans before trying to start up a process in adult humans that was naturally shut down at age two. Although many of the major problems remain to be solved in this difficult area, Thurlbeck never gave up on the idea that emphysematous destruction may be repaired by growing new alveoli, and he continued to think insightfully and encourage new work in this area until he died.

The assessment of the work of a person that you knew well is bound to concentrate on work that you had the privilege of discussing with them frequently while they were alive. This was certainly the case in the present review, and I apologize to his many colleagues who worked with him in areas that I know less about and have not mentioned. His contributions to lung anatomy and pathology were extremely wide ranging, but I believe that the common thread seen in his work was his insistence on quantitative observations that can be correlated with parallel studies of lung function at some level. What I appreciated most about knowing him personally was his seriousness of his commitment to research, and the tremendous enthusiasm, energy and fun that he brought to whatever problem he was trying to solve.

\section{DR JOHN P WYATT}

Dr John P Wyatt provided the first description of the panlobular form of pulmonary emphysema and established a group of experimental pathologists at the University of Manitoba that advanced our understanding of how the injured lung is repaired. Wyatt was born in Winnipeg in 1916, completed secondary education at Kelvin High School before entering the University of Manitoba, and qualified into medicine in 1939. He became a Fellow in Pathology in William Boyd's department at the 
University of Toronto from 1939 to 1941. He was then appointed the Littauer Fellow in Pathology at Harvard University, Cambridge, Massachusetts, that he relinquished after just three months to serve in the Royal Canadian Army Medical Corps in World War II, in which he served with distinction as a pathologist and neuropathologist with the number one Canadian field hospital as the war in the Europe progressed. Following demobilization from the Canadian army in 1945, he resumed his fellowship at Harvard and studied with some of the leading pathologists of the day. He moved back to Toronto in 1947 to take up the positions of Pathologist-inChief at the Toronto East General Hospital and lecturer at the University of Toronto. He was invited to the University of St Louis, Missouri in 1949, and rose from assistant to full professor, Chair of Pathology and Director of Laboratories. He was invited to move back to the University of Manitoba to become the Professor and Head of the Department of Pathology in 1964, and rapidly rejuvenated the teaching programs and built a very productive research program that was focused on lung injury and repair. He left Winnipeg in 1974 for the University of Kentucky, Lexington, Kentucky, where he was in the process of building another fine research laboratory when he developed the illness that led to his death.

I had the privilege of meeting him on several occasions but did not know him well. He struck me as a cultured person who was widely read, and had a serious interest in music and the arts. Although I remember a long conversations with him at a meeting of the Fleischner Society, I got to know about his accomplishments largely from reading his published work. He had a broad interest in pathology and was a competent diagnostic pathologist, as well as an investigator. Early in his academic life, he published on topics that included iron storage and hemosiderosis (44-46), megaloblastic anemia due to folic acid deficiency in pregnancy (47), chronic marrow failure resulting in extramedullary hematopoiesis (48), fat embolism (49), genital tract tumours (50) and cytomegalic inclusion disease (51). His interest in lung disease began at the University of St Louis in the late 1950s and early 1960s, where he published papers on pneumonitis associated with collagen disease (52), pneumoconiosis in coal workers (53), and the relationship between lung disease and hairspray polymers (54). He became interested in the differences in the reported incidence of emphysema between the United Kingdom and the United States, and adopted the whole lung section technique that had been introduced by Gough at the Welsh National School of Medicine, Cardiff, Wales, to show that this difference disappeared when the same techniques were used. This work led to an excellent article on the centrilobular form of emphysema in Laboratory Investigation; A Journal of Technical Methods and Pathology in 1960 (55). That was followed later in the same year with the first description of the panlobular form of emphysema (56). In 1962, an exhaustive study of this form of emphysema based on 275 pairs of necropsy lungs, which included correlations of gross pathology with microscopic lung structure, clinical lung function testing and postmortem measurements of lung gas volumes, pulmonary resistance and angiography, became the definitive work on this subject (57). He continued to work on emphysema after he moved to the University of Manitoba but changed the focus of these investigations to the systemic effects of the disease, with publications on emphysema affecting the heart muscle (58) and glomerular capillary bed (59).
Wyatt re-established research in the Department of Pathology at the University of Manitoba but led it away from postmortem studies toward more basic aspects of experimental pathology. He recruited Drummond Bowden and Ian Adamson to join him, and established an experimental lung pathology group that dominated the field of lung injury and repair for 25 years or longer, earning national and international reputations for all three of these investigators. An excellent review entitled "Lung injury and repair: A contemporary view" published in the Pathology Annual in 1970 (60) indicated the direction that they would take and the published record in PubMed shows that they produced more than 50 publications on this subject between 1968 and 1994. This was about the time that Bowden retired, and this level of productivity continued at a similar level until the more recent retirement of Adamson. I think that Wyatt deserves credit both for establishing this laboratory and for giving his two younger colleagues continued support. Their contributions include the discovery that a pulmonary interstitial cell - now recognized as a monocyte - multiplies within the lung to produce alveolar macrophages (61); the original observations showing that the type 2 cell functions as the progenitor for alveolar regeneration during lung tissue repair (62); and that the type 1 epithelium is derived from type 2 cells in the developing lung (63). These three examples illustrate the high quality of their work, and the fact that it persisted long after Wyatt had moved on to the University of Kentucky is a tribute to the strength of the foundation that he built.

\section{CONCLUSIONS}

Limiting the present brief review to these three Canadian physician scientists provides the reader with a more detailed impression of the quality of the work that has been done in Canada. Furthermore, focusing on persons who have been dead for some time decreases the risk of offence by leaving out some very important contributions of those still living if a more extensive review were attempted. I trust that the choice of Macklin, Thurlbeck and Wyatt offends no one, because they truly transcend the ordinary and give us all a reason to feel proud of being Canadian.

ACKNOWLEDGEMENTS: The author gratefully acknowledges the assistance of Dr Ian Adamson and the Medical School Archives of the University of Manitoba for their assistance in preparing this manuscript.

\section{REFERENCES}

1. Staub NC, Clements JA, Permutt S, Proctor DF. Charles Clifford Macklin, 1883-1959: An appreciation. Am Rev Respir Dis 1976;114:823-30.

2. Barr ML, Buck RC, Jarvis CE. Dr. Charles Clifford Macklin: An appreciation. Can Med Assoc J 1960;82:335.

3. Macklin CC. Vital staining of cells of the mammalian pulmonic alveolar wall and its bearing on the problem of a continuous epithelium. Proc Royal Soc Canada (Section V) Biol Sci 1938;32:156. (Abst)

4. Macklin CC. Argyrophil granular cells in the pulmonic alveolar wall of the kitten. Proc Royal Soc Canada (Section V) Biol Sci 1941;35:196. (Abst)

5. Macklin CC. The pulmonary alveolar mucoid film and the pneumonocytes. Lancet 1954;266:1099-104.

6. Macklin CC, Hartroft S. The size of the pulmonic alveoli based on measurements of outlines in $25 \mu \mathrm{m}$ sections of human and common laboratory animal lungs fixed in a state of expansion. Report to 
Section of Physiology, Chemical Warfare Laboratories: Ottawa; Canada, 1943.

7. Macklin CC. Evidences of an increase in the capacity of the pulmonary arteries and veins of dogs, cats and rabbits during the inflation of the freshly excised lungs. Can Med Assoc J 1946;54:71.

8. Macklin CC. The dust cells in the lungs of the albino mouse; their structure, relations, and mode of action. Lancet 1951;1:432-5.

9. Macklin CC. Lung fluid, alveolar dust drift and initial lesions of disease in the lungs. Can Med Assoc J 1955;72:664-5.

10. Macklin CC. Pulmonary sumps, dust accumulations, alveolar fluid and lymph vessels. Acta Anat (Basel) 1955;23:1-33.

11. Macklin CC. Induction of bronchial cancer by local massing of carcinogen concentrate in out drifting mucus. J Thorac Surg 1956;31:238-44.

12. von Hayek H. The Human Lung. New York: Hafner Publishing Co, 1960.

13. Thurlbeck WM, Benjamin B, Reid L. Development and distribution of mucous glands in the foetal human trachea. Br J Dis Chest 1961;55:54-64.

14. Thurlbeck WM, Benjamin B, Reid L. A sampling method for estimating the number of mucous glands in the foetal human trachea. Br J Dis Chest 1961;55:49-53.

15. Churg AM, Myers JL, Tazelaar HD, Wright JL, eds. Thurlbeck's Pathology of the Lung, 3rd edn. New York: Thieme Medical Publishers, 2005.

16. Thurlbeck WM, Wright JL. Thurlbeck's Chronic Airflow Obstruction, 2nd edn. New York: BC Decker, 1999.

17. Thurlbeck WM. A clinico-pathological study of emphysema in an American hospital. Thorax 1963;18:59-67.

18. Thurlbeck WM, Ryder RC, Sternby N. A comparative study of the severity of emphysema in necropsy populations in three different countries. Am Rev Respir Dis 1974;109:239-48.

19. Thurlbeck WM. The incidence of pulmonary emphysema, with observations on the relative incidence and spatial distribution of various types of emphysema. Am Rev Respir Dis 1963;87:206-15.

20. Thurlbeck WM, Angus GE, Pare JP. Mucous gland hypertrophy in chronic bronchitis and its occurrence in smokers. Br J Dis Chest 1963;57:73-8.

21. Thurlbeck WM, Angus GE. The relationship between emphysema and chronic bronchitis as assessed morphologically. Am Rev Respir Dis 1963;87:815-9.

22. Thurlbeck WM, Angus GE. A distribution curve for chronic bronchitis. Thorax 1964;19:436-42.

23. Thurlbeck WM, Fraser RG, Bates DV. The correlation between pulmonary structure and function in chronic bronchitis, emphysema and asthma. Med Thorac 1965;22:295-303.

24. Thurlbeck WM. Internal surface area and other measurements in emphysema. Thorax 1967;22:483-96.

25. Thurlbeck WM. The internal surface area of nonemphysematous lungs. Am Rev Respir Dis 1967;95:765-73.

26. Hogg JC, Macklem PT, Thurlbeck WM. Site and nature of airway obstruction in chronic obstructive lung disease. N Engl J Med 1968;278:1355-60.

27. Thurlbeck WM. Disease of small airways, with particular reference to lesions found in asymptomatic chronic bronchitis without emphysema. Chest 1973;63:70S-1S

28. Matsuba K, Thurlbeck WM. Disease of the small airways in chronic bronchitis. Am Rev Respir Dis 1973;107:552-8.

29. Berend N, Thurlbeck WM. Exponential analysis of pressure-volume relationship in excised human lungs. J Appl Physiol 1982;52:838-44.

30. Berend N, Thurlbeck WM. Correlations of maximum expiratory flow with small airway dimensions and pathology. J Appl Physiol 1982;52:346-51.

31. Berend N, Skoog C, Thurlbeck WM. Single-breath nitrogen test in excised human lungs. J Appl Physiol 1981;51:1568-73.

32. Berend N, Skoog C, Thurlbeck WM. Exponential analysis of lobar pressure-volume characteristics. Thorax 1981;36:452-5.

33. Berend N, Skoog C, Thurlbeck WM. Lobar pressure-volume characteristics of excised human lungs. Thorax 1981;36:290-5

34. Berend N, Wright JL, Thurlbeck WM, Marlin GE, Woolcock AJ. Small airways disease: Reproducibility of measurements and correlation with lung function. Chest 1981;79:263-8.

35. Berend N, Skoog C, Waszkiewicz L, Thurlbeck WM. Maximum volumes in excised human lungs: Effects of age, emphysema, and formalin inflation. Thorax 1980;35:859-64.
36. Berend N, Skoog C, Thurlbeck WM. Pressure-volume characteristics of excised human lungs: Effects of sex, age, and emphysema. J Appl Physiol 1980;49:558-65.

37. Langston C, Kida K, Reed M, Thurlbeck WM. Human lung growth in late gestation and in the neonate. Am Rev Respir Dis 1984;129:607-13.

38. Langston C, Thurlbeck WM. Lung growth and development in late gestation and early postnatal life. Perspect Pediatr Pathol 1982;7:203-35

39. Thurlbeck WM, Galaugher W, Mathers J. Adaptive response to pneumonectomy in puppies. Thorax 1981;36:424-7.

40. Ford GT, Galaugher W, Forkert L, Fleetham JA, Thurlbeck WM, Anthonisen NR. Static lung function in puppies after pneumonectomy. J Appl Physiol 1981;50:1146-50.

41. Cagle PT, Langston C, Thurlbeck WM. The effect of age on postpneumonectomy growth in rabbits. Pediatr Pulmonol 1988;5:92-5.

42. Langston C, Sachdeva P, Cowan MJ, Haines J, Crystal RG, Thurlbeck WM. Alveolar multiplication in the contralateral lung after unilateral pneumonectomy in the rabbit. Am Rev Respir Dis 1977;115:7-13.

43. Massaro GD, Massaro D. Retinoic acid treatment abrogates elastase-induced pulmonary emphysema in rats. Nat Med 1997;3:675-7.

44. Wyatt JP. Patterns of pathological iron storage. I. The nature and significance of transfusional siderosis and its relationship to idiopathic hemochromatosis and allied conditions. AMA Arch Pathol 1956;61:42-55

45. Wyatt JP. Patterns of pathological iron storage. II. Exogenic siderosis in chronic anemia due to prolonged oral iron medication. AMA Arch Pathol 1956;61:56-61.

46. Wyatt JP, Howell J. Experimental induction of iron overload in the rat. I. Morphological alterations due to dietary siderosis. AMA Arch Pathol 1953;55:466-74.

47. Goldenberg H, Wyatt JP. Megaloblastic anaemia of pregnancy, refractory to liver therapy, but responding to folic acid. Can Med Assoc J 1950;63:289-91.

48. Wyatt JP, Sommers SC. Chronic marrow failure, myelosclerosis and extramedullary hematopoiesis. Blood 1950;5:329-47.

49. Wyatt JP, Orrahood MD. Massive fat embolism following marrow infarction in sickle cell anemia. AMA Arch Pathol 1952;53:233-8.

50. Wyatt JP, Khoo PS. Genital tract tumours of an adenomatoid nature. Br J Urol 1950;22:187-94

51. Wyatt JP, Simon T, Trumbell ML, Evans M. Cytomegalic inclusion pneumonitis in the adult. Am J Clin Pathol 1953;23:352-62.

52. Sante LR, Wyatt JP. Roentgenological and pathological observations in antigenic pneumonitis, its relationship to the collagen diseases. Am J Roentgenol Radium Ther Nucl Med 1951;66:527-45.

53. Wyatt JP. Morphogenesis of pneumoconiosis occurring in southern Illinois bituminous workers. AMA Arch Ind Health 1960;21:445-57.

54. Brunner MJ, Giovacchini RP, Wyatt JP, Dunlap FE, Calandra JC. Pulmonary disease and hair-spray polymers: A disputed relationship. JAMA 1963;84:851-7.

55. Wyatt JP, Fischer VW, Sweet H. Centrilobular emphysema. Lab Invest 1961;10:159-77.

56. Wyatt JP, Sweet H. The morphogenesis of panlobular emphysema. Am Rev Respir Dis 1961;83:426-31.

57. Wyatt JP, Fischer VW, Sweet HC. Panlobular emphysema: Anatomy and pathodynamics. Dis Chest 1962;41:239-59.

58. Ishikawa S, Fattal GA, Popiewicz J, Wyatt JP. Functional morphometry of myocardial fibers in cor pulmonale. Am Rev Respir Dis 1972;105:358-67.

59. Ishikawa S, Bowden DH, Wyatt JP. The glomerular capillary bed in chronic pulmonary emphysema. A pathophysiologic study. Am Rev Respir Dis 1969;100:95-8.

60. Bowden DH, Wyatt JP. Lung injury and repair: A contemporary view. Pathol Annu 1970;5:279-307.

61. Bowden DH, Adamson IY. The pulmonary interstitial cell as immediate precursor of the alveolar macrophage. Am J Pathol 1972;68:521-37.

62. Adamson IY, Bowden DH. The type 2 cell as progenitor of alveolar epithelial regeneration: A cytodynamic study in mice after exposure to oxygen. Lab Invest 1974;30:35-42.

63. Adamson IY, Bowden DH. Derivation of type 1 epithelium from type 2 cells in the developing rat lung. Lab Invest 1975;32:736-45. 


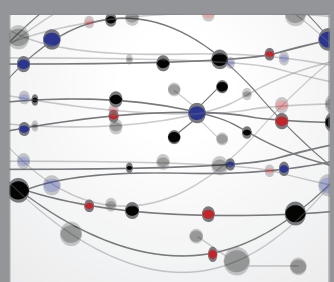

The Scientific World Journal
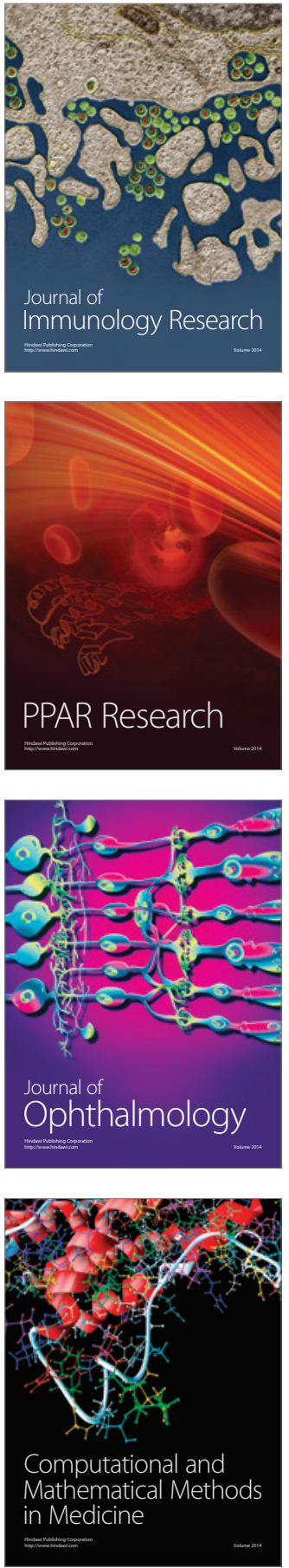

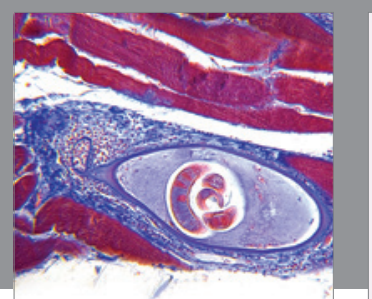

Gastroenterology Research and Practice

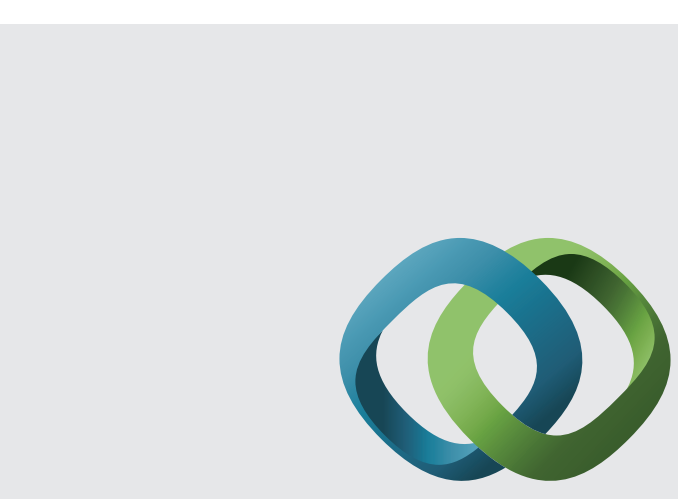

\section{Hindawi}

Submit your manuscripts at

http://www.hindawi.com
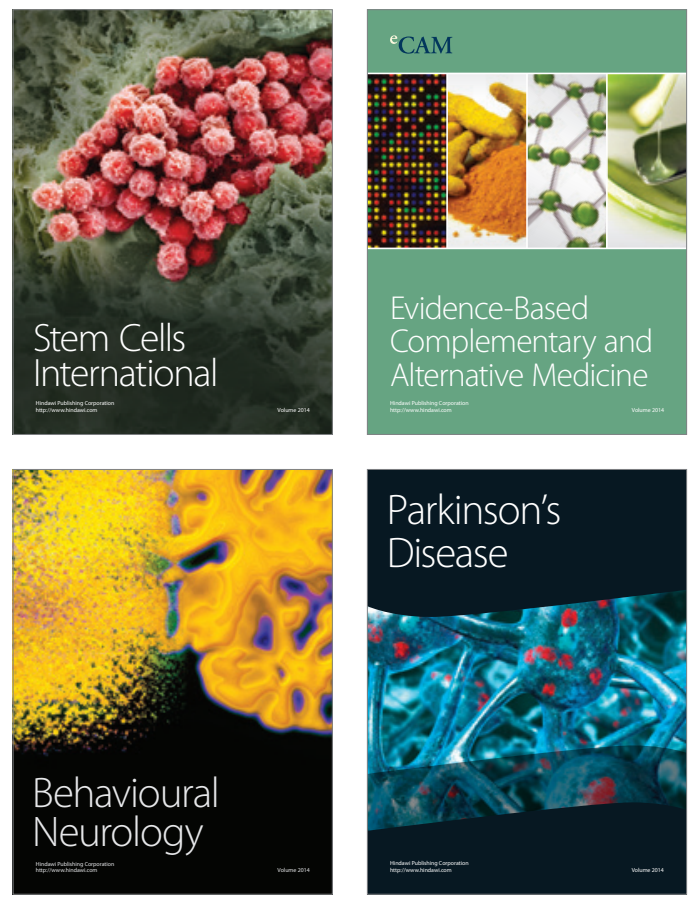
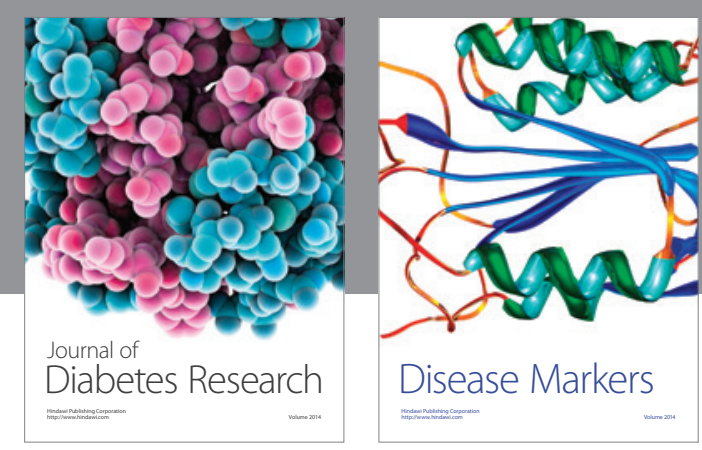

Disease Markers
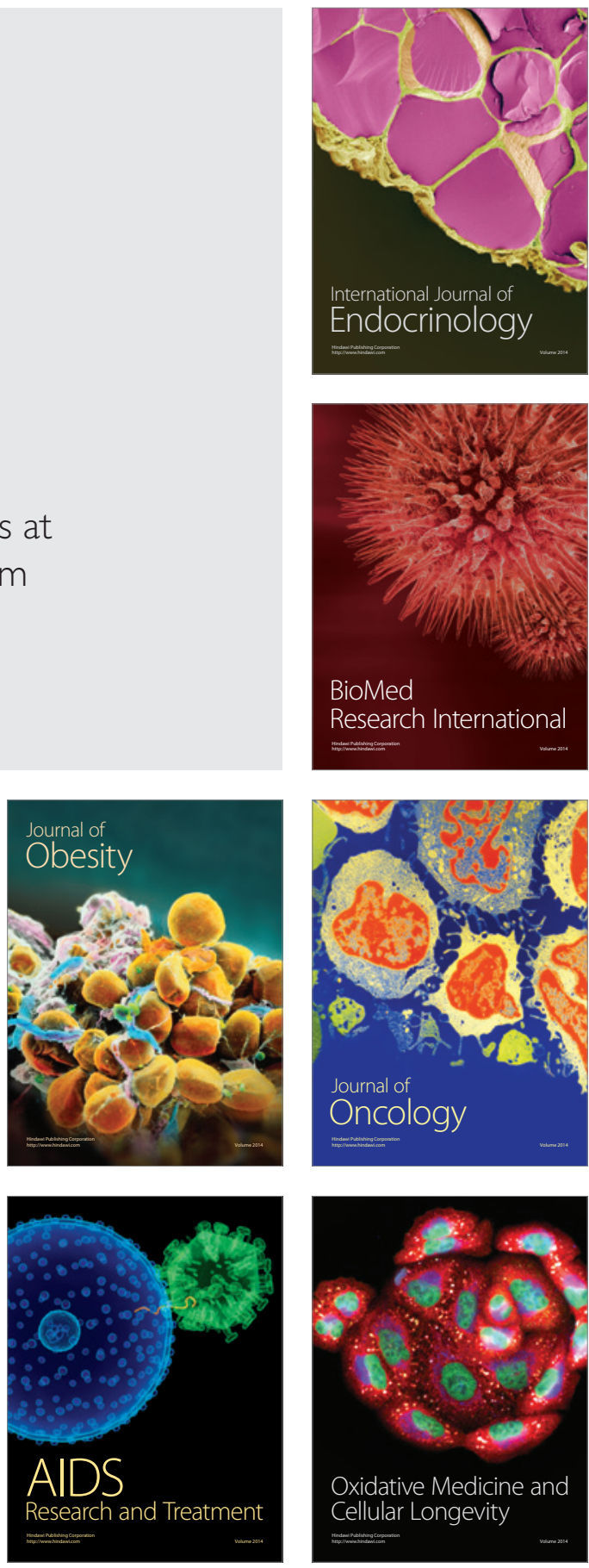